\title{
Phraseological Variations in Medical-Pharmaceutical Terminology and its Applications for English and German into Spanish Translations
}

\author{
Francisco Bautista Becerro ${ }^{\text {a* }}$ \\ ${ }^{a}$ C/Francisco de Vitoria, Facultad de Traducción y Documentación, Universidad de Salamanca, 6, C.P., 37008, Salamanca, Spain .
}

Received 20 December 2019; Accepted 22 February 2020

\begin{abstract}
One of the main characteristics of medical-pharmaceutical language is its extensive, specific and specialized terminology. In texts of this type, precision and accuracy are key factors, and terminological univocity is sought, even though this is not always feasible. Therefore, it is very common to find phraseological units with term value and even periphrases composed of several words. This phenomenon is common in all fields of expertise and, of course, in colloquial language as well, and it is also relevant in medical-pharmaceutical language and in many cases must be taken into account. The purpose of this publication is to analyse certain situations in which terms from the medical-pharmaceutical field have a different phraseological structure in English or German than in Spanish and some types of cases that we may encounter. We not only study these variations and differences between languages, but also the consequences of a poor translation and the possible strategies to avoid it.
\end{abstract}

Keywords: Translation; Medical-pharmaceutical Language; Medical-pharmaceutical Translation.

\section{Introduction}

We wanted to give this study a very practical approach, but based on a theoretical basis. We studied the main phraseological terms and reviewed some important references, which we followed along the article. As for the practical examples, many of them have been taken from real translations, while others have been extracted from studies similar to ours. All of the translation examples cited have been taken from reliable sources, be it dictionaries or specialized websites. Of course, we have only taken into account translation examples which were relevant from a phraseological point of view.

\section{Medical-pharmaceutical Language and its Translation}

The first thing we want to do in this publication is to provide a definition for medical-pharmaceutical language. Many experts remind us how difficult (not to say impossible) it is to delimit a specialized language, in this case the scientific language (and therefore the pharmaceutical language). It is also very difficult to differentiate it from other specialized languages and from the common language [1,2]. Although it is true that a priori it does not seem feasible to establish defined limits for "scientific language", nor for any of its subtypes (here we will include "medicalpharmaceutical language" or simply "pharmaceutical language", and we take the chance to emphasize that we will use both names, sometimes indistinctly), for the purposes of this publication we will try to establish some limits, however diffuse they may sometimes be, and we will define a series of global characteristics. In this case, when we use the term medical-pharmaceutical language, we refer to any language present in texts from medical and pharmaceutical fields: that is, texts that deal with medicines (as well as their use, mechanism of action, research, interactions...), diseases that

*Corresponding author: fran_bautista@usal.es

dol http://dx.doi.org/10.28991/SciMedJ-2020-0201-4

$>$ This is an open access article under the CC-BY license (https://creativecommons.org/licenses/by/4.0/).

(C) Authors retain all copyrights. 
affect human beings or different physiopathological conditions of human beings and that may be present in health institutions, such as hospitals, nursing homes, health centres, pharmacies, pharmaceutical laboratories, etc. Likewise, and in line with Gutiérrez Rodilla [3], we will include all types of communication, be it between specialists or between specialists and non-specialists ${ }^{*}$, and by all channels (both oral and written). We conclude that it is a type of language with a high degree of specialization, and for whose translation "particular skills and abilities" will be needed [4], as well a specific training [5] and the knowledge of «all methodological elements and resources with which to solve terminology issues» [6].

\subsection{Characteristics of Medical-pharmaceutical Language}

Once we have marked the limits of what we understand by medical-pharmaceutical language, we will explain the main characteristics of these types of text. In order to do so, we will cite Gutiérrez Rodilla [1] again, as she reminds us that "one of the most valued characteristics in science is rigour". She lists the following characteristics for scientific language:

- Precision: Gutiérrez Rodilla [1] says precision is "the most valued characteristic in scientific language" and it can refer to the use of explanations or inserts that undo the ambiguities, she associates it with "term precision". Another condition posed by Gutiérrez Rodilla (íbidem) is that, whenever possible, terms must be monosemous and not have synonyms, chimerical as it may seem. This is especially relevant for the purpose of our article, in which we study scientific terms as phraseological units to obtain a greater precision and, therefore, the biggest rigour possible in medical-pharmaceutical texts.

- Neutrality: Gutiérrez Rodilla [1] defines it as “a lack of values and affective or subjective connotations". It may be a desirable characteristic, very important in scientific texts, but we will not study it in depth, as it does not have the phraseological implications we find in precision as a characteristic of the pharmaceutical language.

- Economy: the scientific language "must be expressed using the lowest number of units possible" and searches for a concision linked to the lowest number of words possible, being its main exponent "the replacement of whole sentence by a word". This characteristic is relevant to our study, where we analyse the cases in which a phraseological unit formed by a single term in English or German must be translated by a much larger one in Spanish and vice versa. In fact, although the ideal might be to tend towards simplification, it is inevitable (and very frequent) to use a higher number of words [1].

- Resources employed: in the scientific language it is usual to find "images, schemes, drawings, formulae, diagrams, tables, patterns, etc." [1], mechanisms which do not belong to « any type of message» and which we will not study in depth either, due to their lack of relation with phraseology ${ }^{\dagger}$.

- Scientific vocabulary: Gutiérrez Rodilla [1] claims there are some degree of consensus between authors, who generally agree that, the scientific language vocabulary resources to its "most distinctive and least differentiating aspect". Moreover, she lists further characteristics of the scientific language: it is formed by "adjectives, verbs y, mainly, nouns", which are mostly "made by combinations of Greek and Latin lexemes" (also underlined by Calonge [5]) and that "it shows a quick growth speed" [1]. The result: it is almost impossible to count the terms that make up the scientific language in general and the medical-pharmaceutical one in particular, here is when, once again, we must highlight how important the different phraseological units are, as they give the precision and the accuracy searched for medical-pharmaceutical texts that would otherwise be impossible to reach. This is something all specialised translators must take into account: as Corpas [4] claims, terminology is one of the pillars of scientific translation (together with research ability), in line with Cabré [6]: "terminology is absolutely essential when translating specialised texts".

After having explained what these main characteristics are, we can venture whether it is possible to reach a "perfect" terminology in the medical-pharmaceutical language and even an answer: no. True as it is that terminology in scientific texts is very wide [1] gives an interesting fact: in the first three years of the Medicine degree, students learn around 15,000 new words, a number "much higher than the vocabulary learnt in any basic course of a foreign language"), and recalls that students entering any degree in the scientific and technical field must be confronted not only with learning their own specific knowledge, but also with the language in which that knowledge is expressed [9]. Having said that, we cannot forget that terminology will continue to increase and new terms and phraseological units will continue to be formed to refer to all chemical, biological and physiological phenomena, as well as diseases, chemical compounds, etc.

\footnotetext{
* A typical example is an informed consent, which would be a source of study per se, as it has already been analysed by de Miranda in "El absurdo de la terminología densa en los estudios médicos para pacientes" [2]

${ }^{\dagger}$ It is also important to point out the big amount of symbols, acronyms and abbreviations used in the medical field, which has even lead to the publishing of all kind of glossaries. Examples: "Glosario de símbolos, siglas y abreviaturas de farmacocinética (inglés-español)", by Gallego Borghini and Martín Arias [7]; "Symbols in Pharmacokinetics", by Rowland, Malcolm and Tucker, Geoffrey [8], etc.
} 


\subsection{Phraseological Characteristics of the Medical-pharmaceutical Language}

As mentioned in the previous section, phraseological units are necessary in scientific language in general - and in the medical-pharmaceutical language in particular - to achieve the necessary precision, accuracy and univocality in these texts. To achieve them, as we have already seen, it is very common to resort to phraseological units and periphrases, units composed of two words or more which manage to fulfil this purpose. In this article we abide by the phraseological units definition proposed by, for example, Penadés [10]: "a fixed combination of words which, in many cases, has a meaning which is not apparent from the meaning of its constituent elements" and by Martínez Marín [11]: units that have semantic content as well as other linguistic elements. Furthermore, since we are talking about a specialized semantic field, we will also refer to them as specialized phraseological units (SPU), specialized meaning units (SMU) with the following properties [12]: they include a terminological unit (TT), which can be simple or syntagmatic, include an element with an eventual value from which the discourse is semantically organized, have a certain degree of fixation determined by the semantic relationship established between its elements, rather than by the syntactic relationships, and have a relevant frequency in the set of texts in which they appear (in this case, the medicalpharmaceutical ones). In other words, some of Bevilacqua (2004) studies' requirements are its syntagmatic character, its syntactic and semantic stability or its use in a specific field [13].

SPU are necessary in specialized fields [14] and are often studied «in the same way as terminology» (íbidem). In this article we have adopted a similar approach and below we will list a number of examples of phraseological units which belong to a different category in English or German than in Spanish, as well as their translation. Following the definitions given in previous paragraphs, we deliver SPUs with a different phraseological structure in the languages in question.

\section{Phraseological Variations in the Translation of Medical-pharmaceutical Texts from English into Spanish}

Medical-pharmaceutical translation from English into Spanish is a market that moves millions of euros in the whole world and in which absolute rigour is sought and required ${ }^{*}$, as the consequences of a mistranslation can be fatal. In order to achieve it, it is necessary to adapt the original text to Spanish, and on many occasions this requires the use of different phraseological units in both languages, although it is also common to find translation errors of many kinds [16]. The different cases that we intend to analyse in this article are the following ones (for reasons of space, we can only give a limited number of examples in each case).

\subsection{Verbs}

The first section is dedicated to verbs and, in particular, to the famous phrasal verbs, a real headache for students of English, but also a very interesting structure from a phraseological point of view. These verbs are composed of two words (verb + preposition) and have a very specific meaning. They do not exist as such in Spanish and their translation will be, in almost all cases, a verb or a verbal periphrasis. Although they are not specific or exclusive to pharmaceutical texts, and although we have already seen that the predominant grammatical category in scientific language is the noun, and phrasal verbs usually have higher register than non-prepositional equivalents, we do want to provide a list of some of the most frequent ones in this field:

- Get over: recuperarse (de una enfermedad);

- Pass away: fallecer;

- Pass out: desmayarse, perder el sentido;

- Pick up: contraer (una enfermedad);

- Rule out: in El Libro rojo [17], A. Navarro defines it as «descartar en el sentido de excluir o rechazar una posibilidad diagnóstica o de otro tipo». ${ }^{\dagger}$ Apart from being a verb widely used in scientific texts, the word rule is a basis for other phraseological units: rule of nines (regla de los nueves), work-to-rule (huelga de celo), Markownikoff rule (regla de Markóvnikov), etc.

- Throw up: vomitar.

\footnotetext{
* As Fernando A. Navarro states, clinical research (especially pharmaceutical research) is one of the pillars of the translation market: a great amount of written information is continually produced, which must be translated. Translators must, therefore, know about medicine, pharmacy, epidemiology, etc. https://medicablogs.diariomedico.com/laboratorio/2018/07/24/diccionario-ingles-espanol-de-investigacion-clinica/ [15]

${ }^{\dagger}$ To rule out in the sense of "to exclude or to reject a diagnosis possibility or of other kind [17].
} 


\subsection{Nouns}

This section is dedicated to phraseological structures belonging to the substantive grammatical category in English and Spanish. As we have previously mentioned, nouns are especially relevant in medical-pharmaceutical texts and are the most common type of word. Below, we list a series of examples:

- Drug-drug interactions: this structure formed by three nouns, the first two of which have an adjective function, will ideally be translated as interacciones farmacológicas (better than the calques interacciones fármacofármaco, interacciones droga-droga or interacciones entre fármacos, which would be the equivalents in Spanish with the same phraseological structure. On the other hand, there is another type of interaction (drug-body interaction) whose translation keeps the same structure: interacción entre fármaco y organism [17], also interesting from a phraseological point of view because it is necessary to add the preposition entre.

- Cost-effectiveness: in many cases, English allows greater grammatical flexibility in word order and grammatical function. In Spanish, fortunately, in this case we have a term that has the same meaning with only one word: rentabilidad. As stated by Fernando A. Navarro", «it is much more concise than the common calque relación coste-efectividad». This term is also widely used in Pharmacoeconomics, and it is often translated as eficiencia.

- Low back pain (also lower back pain, lower back ache, low back ache or even lumbar pain): if we were to translate it literally, the result would be an 8-word SPU (dolor en la parte baja de la espalda), while also in this case Spanish has a single word to express the same meaning: lumbalgia (or lumbago), with which we get the textual economy defended by Gutiérrez Rodilla [1] without lacking precision.

- Stroke: contrary to the previous examples, this simple word in English has a much longer translation in Spanish: accidente cerebrovascular, which fortunately can be shortened using the accronym $A C V$.

\subsection{Adjectives}

Having seen a number of examples of verbs and nouns with phraseological relevance in the writing and translation of pharmaceutical texts, we would also like to name a number of adjectives:

- Compassionate: this term is common in medical texts, and Fernando A. Navarro [17] accepts translating it as compasivo in certain cases, but also the use of the phrase «por motivos humanitarios». He also gives us another example: compassionate leave, whose translation would be permiso por motivos familiares (SPU formed by a noun and a prepositional syntagm).

- Impaired: this term is widely used in medical-pharmaceutical texts, to the point that it can be translated into Spanish in many different ways: using adjectives (alterado, inválido...) and, what's most importan for our study, different phraseological studies. Some examples are renally impaired patients (pacientes con insuficiencia renal), impaired growth (retraso del crecimiento), impaired hearing (hipoacusia, deficiencia auditiva), impaired immune system (inmunodeficiencia), impaired metabolism (trastorno metabólico), etc.

\subsubsection{Phraseological Units Formed by an Adjective (or Adjective Function) + Noun}

Although in some of the previous examples we have seen how the phraseological units in Spanish change when an adjective is added before a noun (and vice versa), there are other terms formed by more than one word and with the adjective + noun structure whose translation into Spanish is interesting from a phraseological point of view because of the structural differences we find. Below are some examples of special interest or relevance.

- Cardiac death: its literal translation muerte cardiaca does not work in Spanish because it would mean "death of the heart" (muerte del corazón) [17]. The right translation would be muerte de causa cardiaca or muerte de origen cardiaco. Fernando A. Navarro explains this in his Libro rojo ${ }^{\dagger}[17]$ and gives other similar examples with different phraseological structures when translated: cardiovascular death (muerte por causas cardiovasculares) and cell death (muerte celular).

- Clinical trial: although the first translation option, globally accepted, is estudio clínico or ensayo clínico, there are many types of clinical trials, and some of them give us interesting translations

- Crossover clinical trial (estudio [or ensayo] clínico con grupos cruzados): crossover is a noun with adjective function and without an equivalent in Spanish; therefore, in its translation we need a prepositional syntagm with adjective function.

\footnotetext{
* Entry for cost-effectiveness in El Libro rojo (Diccionario de dudas y dificultades de traducción del inglés médico (3. a edición) Version 3.13; March 2019) [17].

${ }^{\dagger}$ Entry for cardiac death in El Libro rojo (Diccionario de dudas y dificultades de traducción del inglés médico (3. ${ }^{\text {rd }}$ edition) Version 3.13; March 2019).
} 
- Phase I clinical trial (estudio [or ensayo] clínico de fase I): once more, a noun (phase I) acquires an adjective function before clinical trial, so we need a prepositional syntagm again.

- Graft-versus-host disease: this phraseological unit has a very interesting structure because the adjective function is fulfilled by a nominal syntagm. Its translation is equally interesting. Though the phrases enfermedad del injerto contra el anfitrión (EICA) and mainly enfermedad injerto contra huésped are widely settled in the Spanish language, its mechanism and aetiology make Fernando A. Navarro [17] suggest a more simple option, with a different phraseological structure: rechazo inverso* .

- Investigational new drug (IND): this term is widely used in scientific articles, and the Spanish translation would be productos en fase de investigación clínica. As we can see, the phraseological structure is totally different, as Spanish does not have such an adjective as investigacional.

- Rate: although in English it can work as a verb, we will focus on some constructions in which it has a noun function and is accompanied by other words with an adjective function:

- New case rate: contrary to what is usual, Spanish has a simpler construction (two nouns instead of three): tasa de incidencia.

o Birth death rate: this construction, formed by three nouns (the first two with an adjectival function) is translated into Spanish with a prepositional construction formed by a noun preceded by the preposition de: tasa [or índice] de mortinatalidad [17].

- Erythrocyte sedimentation rate: once again, the two nouns with adjective function can be translated into Spanish using a prepositional syntagm. Similarly, we must emphasize the fact that one of the options implies a noun with a prefix: velocidad de sedimentación globular, velocidad de eritrosedimentación.

- Pulse rate: the huge polysemy of rate in English makes its use in Spanish different to the point that it can be omitted. It is the case of pulse rate, translated into Spanish as número de pulsaciones, or simply pulso. Something similar happens with absorption rate constant (constante de absorción) or basal metabolic rate (metabolismo basal) [17]. Keeping rate in Spanish in these cases would make the texts longer and even hinder its understanding. Therefore, it would be a translation mistake.

- Immune: it can be translated as inmunitario, inmunológico or inmunizante (depending on the context and avoiding «inmune»), but in this article we will focus on the cases in which Spanish uses the prefix 'inmuno-' as a translation for the English noun immune, e. g., immune body (anticuerpo) or immune cell (inmunocito). Once again, a literal translation (¿cuerpo inmune?) would be a serious mistake and would expose the translator's lack of knowledge and methodology.

\section{Phraseological Variations in the Translation of Medical-pharmaceutical Texts from German into Spanish}

There are many differences between the grammatical structure of German and Spanish that make it necessary to use different phraseological units when translating a text (from any field) from German into Spanish. Below, we will list some of the most frequent ones and give examples belonging to the medical-pharmaceutical field.

\subsection{Separable Verbs}

In line with the English phrasal verbs, German has its separable verbs, characterized by a particle-prefix which in declarative and interrogative indicative phrases is placed in the last position, something which obviously does not occur in Spanish.

Table 1. Some of the verbs of this type frequent in medical-pharmaceutical texts

\begin{tabular}{ccc}
\hline German & Spanish & English \\
\hline anpassen & adaptar & to adapt \\
ansprechen & corresponder & to correspond \\
beitragen & contribuir & to contribute \\
darstellen & representar & to represent \\
feststellen & asegurar & to establish \\
fortfahren & continuar & to continue \\
nachgehen & seguir, perseguir & to pursue \\
vorsehen & prever & to foresee \\
\hline
\end{tabular}

\footnotetext{
* In the entry graft-versus-host disease from El Libro Rojo (Diccionario de dudas y dificultades de traducción del inglés médico (3. ${ }^{\text {rd }}$ edition) Version 3.13; March 2019).
} 


\subsection{Nouns}

We will dedicate this section to a specific type of noun: the famous German Komposita. Composition is a morphological procedure with which some languages can combine lexemes to create new words. This mechanism is highly productive both in Spanish and in German [18] and, what interests us, widely used in the medicalpharmaceutical language, where the need of precision makes it necessary. Below are listed some examples:

- Abdominalsyndrom: good example of word formed by two lexemes (Abdominal- + -syndrom) and also a word whose translation can be confusing, as the right choices would be peritonismo or seudoperitonitis, but not "síndrome abdominal" [19].

- Kastrationsresistente Prostatakarzinom: this is a very specific disease, and its translation into Spanish would be cáncer de próstata resistente a la castración. While the SPU in German is composed of two words, the first of which is formed adding an adjective to a noun and the second formed by two nouns together, the resulting SPU in Spanish has no fewer than seven words.

- Transkriptionsfaktoren: a simple example of hoy a noun syntagm in Spanish (factores de transcripción) can be expressed in German with only one word.

- [Polymerase]-Kettenreaktion: reacción en cadena [de la polimerasa]. Once again, we see that the phraseological units are different in German and Spanish due to the fact that Spanish lacks a mechanism like composition.

- Röntgenstrahlen: literally, "rayos de Röntgen” (Röntgen's rays), and rayos X in Spanish (X-ray). This term is especially interesting because of all the words that come from the name Röntgen: Röntgentherapie (radioterapia, radiotherapy), Röntgenbild (radiografía, radiograph), Röntgenologie (radiología, radiology), Röntgenarzt (radiólogo, radiologist), Röntgendermatitis (radiodermatitis, actinodermatitis), röntgen (radiografiar, to X-Ray), Röntgendiagnostik (radiodiagnóstico, diagnosis radiology), etc. [19].

\subsubsection{Phraseological Curiosities in Translations from German into Spanish}

The ease with which the process of composition is used in German makes it possible to obtain words with a bigger precision. It also gives rise to words that we may consider curious because of their structure, origin or meaning. In addition to those listed above, we would like to provide the following examples:

- Hausapotheke: it literally means a "house pharmacy". It is interesting because in English we would need more than one word (first-aid kit, medicine cabinet, etc.) while in Spanish it can be expressed with just one word: botiquín.

- Krankengymnastik: it literally means "gymnastics for the sick", but its right translation would be fisioterapia in Spanish and physiotherapy in English. It is important to be careful, as the German word Physiotherapie, exists, just with a more general meaning referring to all treatments by physic means [19].

- Meerschweinchen: it literally means «sea piglet», but it is the name of the most ubiquitous animal used for research: the cobaya or Guinea pig.

\subsection{Adjetives}

- Alzheimersche Krankheit: it is not difficult to guess this is the German word for enfermedad de Alzheimer (or simply alzhéimer, as it is often used in Spanish) or Alzheimer's disease in English. However, it is remarkable to see that the adjective is an eponym (the disease is named after the German doctor Alois Alzheimer) ${ }^{*}$. In the same line, we find Addisonsche Krankheit (enfermedad de Addison in Spanish, Addison disease in English), Bornholmer Krankheit (pleurodinia epidémica [de Bornhorn] in Spanish, devil's grip in English) or Basedowsche Krankheit (enfermedad de Graves-Basedow, also known in Spanish as hipertiroidismo, bocio exoftálmico hipertiroideo; in English: Graves disease). This last one would give rise to other discussions about eponyms, but we will leave it here.

- Englische Krankheit: it literally means "English disease", but both Spanish and English have very different words to express it: raquitismo and rickets.

\section{Conclusion}

Once we have provided a possible definition for "pharmaceutical language" and studied some of the translation strategies for specific terms in which the result is a different phraseological unit, we can draw a number of conclusions. For example, it is important to take into account the different grammatical structures of English and German and not to stick to the originals when translating into Spanish. Although this is fundamental in all

\footnotetext{
More information in the entry for «Alzheimer» from EL Libro Rojo [17].
} 
translations, and is by no means an aspect exclusive to pharmaceutical language, in this type of text it can be crucial due to the contexts in which we will find them (hospitals, research centres...) and the importance of their content. The examples listed are common in this type of texts and we must know how to deal with their translation or, since we are talking about different syntactic structures, transposition. For example, in English, the structure adjective + noun often call for a prepositional syntagm in Spanish, the same which happens with the German Komposita, although we cannot forget the cases in which the opposite happens. For all these reasons, and emphasizing once again the importance of precision in medical-pharmaceutical texts, we consider it essential to continue researching phraseological units to help provide this precision, which is desired in these texts. Similarly, we emphasize once again the importance of a correct use of terminology, often consisting of phraseological units of different number of words between the source and target languages, as we have seen repeatedly in this article

\section{Declaration of Competing Interest}

The authors declare that they have no known competing financial interests or personal relationships that could have appeared to influence the work reported in this paper.

\section{Ethical Approval}

All procedures performed in studies involving human participants were in accordance with the ethical standards of the institutional and/or national research committee and with the 1964 Helsinki declaration and its later amendments or comparable ethical standards.

\section{References}

[1] Gutiérrez Rodilla, B. M. (2005). El lenguaje de las ciencias.

[2] De Miranda, E. (2018). El absurdo de la terminología densa en los estudios médicos para pacientes. Panace@ @ 47(19), 3-4.

[3] Cabré, M. T., Domènech, M., Morel, J. and Rodríguez, C. (2001). La terminología científico-técnica. Institut Universitari de Lingüística Aplicada.

[4] Corpas Pastor, G. (2004). La traducción de textos médicos especializados a través de recursos electróncios y corpus virtuales. Las palabras del traductor. Actas del II Congreso Internacional “El español, lengua de traducción” 20 137-164.

[5] Calonge Prieto, M. (2009). La complejidad del lenguaje de los textos médicos y la terminología especializada. Nociones para el estudiante de traducción médica (inglés-español). Panorama actual del estudio y la enseñanza de discursos especializados. Ed. by María-José Varela Salinas.

[6] Cabré Castellví, M. T. (2004). La terminología en la traducción especializada. Manual de documentación y terminología para la traducción especializada, 89-122. Ed. by Gonzalo García, Consuelo; García Yebra, Valentín.

[7] Gallego Borghini, L. and Martín Arias, J. M. (2018). Glosario de símbolos, signos y abreviaturas de farmacocinética (inglésespañol). Panace@.47(19), 22-35.

[8] Rowland, Malcolm and Tucker, Geoffrey (1982) Symbols in Pharmacokinetics. In Br. J. clin. Pharmac. 14, 7-13.

[9] Gutiérrez Rodilla, B. M. and Quijada Diez, C. 2014 El lenguaje médico en los planes de estudios de las titulaciones biosanitarias. La importancia del lenguaje en el entorno biosanitario. 53-62.

[10] Penadés Martínez, I. (2000). La hiponimia en las unidades fraseológicas. Cádiz: Universidad de Cádiz.

[11] Martínez Marín, J. 2000. El significado de las unidades fraseológicas en los diccionarios monolingües del español: el caso de las locuciones. Las lenguas de Europa: estudios de fraseología, fraseografía y traducción. Ed. by Gloria Corpas Pastor.

[12] Bevilacqua, C. (2001). Unidades fraseológicas especializadas (UFE): elementos para su identificación y descripción. La terminología científico-técnica. 113-141. Ed. by María Teresa Cabré and Judit Feliu. Institut Universitari de Lingüística Aplicada.

[13] Bevilacqua, C. (2004). Unidades fraseológicas especializadas eventivas: descripción y reglas de formación en el ámbito de la energía solar. Universidad Pompeu Fabra.

[14] Sevilla Muñoz, M. 2015. Las unidades fraseológicas del discurso científico-técnico y su traducción (inglés-español). Enfoques actuales para la traducción fraseológica y paremiológica: ámbitos, recursos y modalidades. 239-256. Ed. by Germán Conde Tarrío, Pedro Mogorrón Huerta, Manuel Martí Sánchez and David Prieto García-Seco.

[15] Navarro, Fernando A. 2018. Diccionario inglés-español de investigación clínica (Laboratorio del lenguaje). Available online: https://medicablogs.diariomedico.com/laboratorio/2018/07/24/diccionario-ingles-espanol-de-investigacion-clinica/ 
[16] Acosta Artiles, F. J. and Bolaños Medina, A. (2017). Anglicismos léxicos evitables en artículos científicos de salud mental. Panace@.45(18), 3-11.

[17] Navarro, Fernando A. 2019. Diccionario de dudas y dificultades de traducción del inglés médico (3.rd edition) Version 3.13; March 2019. Available online: http://www.cosnautas.com/es

[18] Torijano, J. A. y Recio Ariza, M. A.: La problemática de los Komposita en la fraseología. Lenguas en contacto, ayer y hoy. Traducción y variación desde una perspectiva filológica. 383-404. Ed. by Santiago del Rey Quesada, Florencio del Barrio de la Rosa and Jaime González Gómez.

[19] Navarro, F. A. 1997. Palabras alemanas de traducción engañosa en medicina. Monografías Dr. Antonio Esteve. Traducción y lenguaje en medicina. 69-82. Ed. by Fernando A. Navarro. 